\title{
PENGARUH SINBIOTIK KEFIR PISANG BATU TERHADAP KADAR KOLESTEROL-LDL DAN KOLESTEROL-HDL TIKUS MODEL SINDROM METABOLIK
}

\section{Effect of Banana Kefir Synbiotic on LDL-Cholesterol and HDL-Cholesterol of Metabolic Syndrome Rats}

\author{
Dina Khoiriyah*, Taufik Maryusman, Santi Herlina \\ Program Studi IImu Gizi, Fakultas IImu Kesehatan, Universitas Pembangunan Nasional "Veteran" Jakarta \\ JIn. RS Fatmawati, Pondok Labu, Jakarta Selatan 12450 \\ *Email: dkdina12@gmail.com
}

\begin{abstract}
Metabolic syndrome (SM) is characterized by several risk factors including dyslipidemia. This study aims to analyze the effect of kefir synbiotic produced from banana stone flour (Musa balbisiana) on LDL-cholesterol and HDL-cholesterol of metabolic syndrome rat model. The 24 Sprague Dawley rats were divided into four groups, namely negative control (healthy rats fed standard feed), positive control (metabolic syndrome rats fed standard feed), treatment I and treatment II (metabolic syndrome rats each given synbiotic kefir banana stone flour $1.8 \mathrm{~mL} / 200$ $g$ mouse BW/day and $3.6 \mathrm{~mL} / 200 \mathrm{~g}$ mouse BW/day, respectively). The intervention was carried out for three weeks. After the intervention, the levels of $L D L$-cholesterol in treatment I and II experienced a decrease of $44.66 \%$ and $56.94 \%$, respectively, while the-HDL-cholesterol levels in treatment I and II experienced an increase of $104.5 \%$ and $172.71 \%$, respectively. The biggest change occurred in treatment II. Synbiotic kefir banana stone flour improved lipid profile in metabolic syndrome rats.
\end{abstract}

Keywords: kefir, HDL-cholesterol, LDL-cholesterol, metabolic syndrome, synbiotic

\begin{abstract}
ABSTRAK
Sindrom metabolik (SM) ditandai dengan beberapa faktor risiko termasuk dislipidemia. Penelitian ini bertujuan untuk menganalisis pengaruh sinbiotik kefir tepung pisang batu (Musa balbisiana) terhadap kadar kolesterol-LDL dan kolesterol-HDL tikus model SM. Subjek menggunakan 24 ekor tikus Sprague Dawley yang dibagi menjadi empat kelompok, yaitu kontrol negatif (tikus sehat yang diberi pakan standar), kontrol positif (tikus model SM yang diberi pakan standar), perlakuan I dan perlakuan II (tikus model SM yang masing-masing diberi sinbiotik kefir tepung pisang batu 1,8 mL/200 g BB tikus/hari dan 3,6 mL/200 g BB tikus/hari). Proses intervensi dilakukan selama tiga minggu. Setelah intervensi, kadar kolesterol-LDL perlakuan I dan II mengalami penurunan sebesar $44,66 \%$ dan $56,94 \%$, sedangkan kadar kolesterol-HDL perlakuan I dan II mengalami peningkatan sebesar $104,5 \%$ dan $172,71 \%$. Perubahan terbesar terjadi pada perlakuan II. Sinbiotik kefir tepung pisang batu memperbaiki profil lipid tikus sindrom metabolik.
\end{abstract}

Kata Kunci: kefir, kolesterol-LDL, kolesterol-HDL, sinbiotik, sindrom metabolik 


\section{PENDAHULUAN}

Sindrom metabolik adalah kondisi dimana seseorang mengalami gangguan metabolik seperti obesitas sentral, hipertensi, dislipidemia, resistensi insulin yang meningkatkan risiko terhadap penyakit makrovaskular (Srikanthan et al. 2016, Joseph et al. 2017). Kombinasi dari tiga atau lebih gejala tersebut menandakan kondisi sindrom metabolik yang dapat meningkatkan risiko penyakit kardiovaskular. Hal tersebut ditandai dengan dislipidemia berupa peningkatan kadar kolesterol-LDL (lowdensity lipoprotein) dan penurunan kadar kolesterol-HDL (high-density lipoprotein) (Bhambhani dkk. 2015, Gill et al. 2017). Di Indonesia prevalensi sindrom metabolik sebesar 23\% (Suhaema dan Masthalina 2015), dengan kejadian sindrom metabolik pada kelompok lanjut usia sebesar 14,9\% (Kamso 2007). Sedentary Lifestyle yakni pola hidup yang gemar mengonsumsi makanan tinggi kalori dan rendahnya aktifitas fisik dapat meningkatkan risiko terjadinya sindrom metabolik (Octavia dkk. 2017). Penatalaksanaan non farmakologis dengan memanfaatkan pangan fungsional seperti sinbiotik diperlukan sebagai intervensi lini pertama untuk pencegahan terjadinya sindrom metabolic (Salsabila et.al.2020).

Sinbiotik merupakan kombinasi probiotik dan prebiotik yang menimbulkan efek sinergis terhadap kesehatan manusia (Rahmawati dkk. 2017). Sinbiotik bermanfaat untuk meningkatkan taraf hidup dan memperbaiki saluran cerna dengan merangsang pertumbuhan mikroba baik dalam tubuh (Pandey et al. 2015). Sinbiotik juga berperan dalam metabolisme lemak terutama dalam menurunkan kadar kolesterol-LDL dan meningkatkan kadar kolesterol-HDL secara signifikan (Aktimur et al. 2017).

Tikus hiperkolesterolemia yang diberikan produk sinbiotik dengan tepung gembili sebanyak $4 \mathrm{~mL} /$ hari selama 2 minggu memberikan efek positif yakni adanya perbaikan profil lipid darah dengan menurunnya kadar kolesterol total tikus (Saputra dan Margawati 2015).

Penelitian lainnya juga menunjukkan bahwa konsumsi sinbiotik berupa yoghurt sebagai probiotik dengan tambahan kacang merah sebagai prebiotik selama 15 hari dapat menurunkan kadar kolesterol-LDL pada wanita dislipidemia (Nur Cahyo dan Kartasurya 2015).

Probiotik diartikan sebagai mikroba hidup yang memberikan manfaat untuk kesehatan manusia (Pandey et al. 2015). Probiotik memiliki efek hipokolesterolemik yakni dengan memproduksi bile salt (Anandharaj et al. 2014). Probiotik juga memiliki peran dalam menurunkan sintesis kolesterol di hati dengan menghambat enzim 3-hidroksi-3-methylglutaryl coenzyme A reduktase (HMG-CoA reduktase) sehingga terjadi penurunan sintesis dan sekresi kolesterol-LDL (Towil dan Pramono 2014, Cho dan Kim 2015). Salah satu produk yang mengandung probiotik adalah kefir (El-Bashiti et al. 2017). Kefir dikenal sebagai produk fermentasi berbahan dasar susu yang dibuat melalui inokulasi starter kefir yang terdiri dari bakteri asam laktat (BAL) dan yeast (Martharini dan Indratiningsih 2017, Tonucci et al. 2017). Peningkatan produksi bakteri probiotik dapat dihasilkan dari hubungan yang saling menguntungkan antara yeast dan bakteri (Carasi et.al. 2015). Kefir dapat terbuat dari susu kambing (200 $\mathrm{mL})$ mengandung kadar lemak $2 \%$, kadar protein $4 \%$, kadar laktosa $>3,7 \%$ (Hardiansyah 2020).

Penelitian pendukung menunjukkan bahwa pemberian kefir sebanyak $0,1 \%$ bermanfaat dalam penurunan kadar kolesterol-LDL dan peningkatan kadar kolesterol-HDL pada mencit (Choi et al. 2017). Kejadian dislipidemia dapat dicegah dengan mengonsumsi gabungan antara kefir dan prebiotik yang bermanfaat positif bagi tubuh (Pimenta et.al. 2018)

Prebiotik diartikan sebagai substrat atau makanan yang dapat meningkatkan ketahanan bakteri probiotik (Darilmaz et al. 2018). Prebiotik seperti inulin, frukto oligosakarida dan pati resisten bermanfaat sebagai nutrisi bagi bakteri probiotik (Abhari et al. 2015). Prebiotik memiliki efek hipotrigliserida melalui peningkatan short chain fatty acid (SCFA) dengan menghambat aktivitas enzim lipogenik di dalam hati sehingga dapat menurunkan sekresi kolesterol-LDL (Towil dan Pramono 2014, Verbeke et al. 2015). Prebiotik menghambat pemecahan lemak dalam hati melalui produksi SCFA selama fermentasi kolonik (Rusdiana dan Syauqy 2015). Sumber 
pangan dengan kandungan prebiotik jenis pati resisten yang relatif tinggi dan mudah ditemui di Indonesia adalah pisang batu (Musa balbisiana) (Musita 2014).

Tepung pisang batu mempunyai kandungan pati resisten lebih tinggi dibandingkan jenis pisang lainnya, yaitu sebesar $39,35 \%$ sehingga pemanfaatannya dapat dioptimalkan (Musita 2012, Wahyuni dan Syauqy 2015). Penelitian pendukung oleh de Angelis-Pereira et al. (2013) menyatakan bahwa pemberian daging pisang sebesar $7 \%$ dan kulit pisang sebesar 1\% pada tikus hiperkolesterol kurang optimal dalam perbaikan fraksi lipid dibanding dengan pemberian kefir sehingga dibutuhkan kombinasi dari keduanya untuk menimbulkan efek sinbiotik.

Penelitian mengenai pemberian fermentasi kefir susu kambing dengan porang glukomanan yang mengandung tinggi serat terbukti dapat menurunkan kadar malondialdehid (MDA) (Nurliyani dkk. 2017), kadar kolesterol-LDL dan meningkatkan kadar kolesterol-HDL (Nurliyani et al. 2018) secara signifikan pada tikus jenis Sprague Dawley yang mengalami sindrom metabolik. Namun penelitian mengenai kefir sinbiotik dengan penambahan tepung pisang batu belum ditemukan, sehingga penelitian ini bertujuan untuk menganalisis pengaruh sinbiotik kefir tepung pisang batu terhadap profil lipid (yaitu kadar kolesterol-HDL dan kolesterol-LDL) tikus model sindrom metabolik yang sebelumnya belum pernah dilakukan.

\section{BAHAN DAN METODE}

\section{Tempat dan waktu penelitian}

Penelitian dan pengumpulan data dilakukan dalam rentang waktu Maret-Juli 2019. Penelitian pembuatan sinbiotik tepung pisang batu dilakukan di Laboratorium Teknologi Pangan, Universitas Gadjah Mada. Sedangkan penelitian uji preklinis dilakukan di Laboratorium Pusat Studi Pangan dan Gizi, Universitas Gadjah Mada.

\section{Bahan}

Bahan yang digunakan dalam penelitian ini, yaitu: 1) susu skim kambing, starter bakteri (Lactobacillus lactis, $L$. cremoris, L. diacetylactis, dan ragi Saccharomyces cerevisiae dan S. lactis), serta tepung pisang batu ( $M$. balbisiana) dalam pembuatan sinbiotik kefir tepung pisang batu, 2) kuning telur bebek, minyak babi, fruktosa murni, pakan standar (comfeed AD II), akuades, sinbiotik kefir tepung pisang batu, reagen kolesterol-LDL (heparin dan sodium citrate), reagen kolesterol-HDL (phosphotungstic acid dan magnesium chloride), dan sampel serum darah hewan coba untuk uji pre klinis. Pisang batu $(M$. balbisiana) didapatkan dari kebun di Kecamatan Limo, Depok, Jawa Barat (S $6^{\circ}$ 22' 34.81”, E $\left.106^{\circ} 47^{\prime} 19.118^{\prime \prime}\right)$.

\section{Metode}

Penelitian menggunakan desain true experimental dengan rancangan pre-post test control group design. Variabel independen penelitian ini adalah pemberian sinbiotik kefir tepung pisang batu sedangkan variabel dependen adalah kadar kolesterol-LDL dan kolesterol-HDL.

Rancangan penelitian ini menggunakan hewan coba yang dibagi secara acak menjadi 4 kelompok, yaitu kelompok kontrol negatif $(\mathrm{K}-)$, kelompok kontrol positif $(\mathrm{K}+)$, kelompok perlakuan I $(\mathrm{PI})$, dan kelompok perlakuan II (PII) (Gambar 1). Kelompok K- adalah tikus dalam kondisi sehat yang diberikan pakan standar. Kelompok $\mathrm{K}+$ adalah tikus model sindrom metabolik yang diberikan pakan standar. Kelompok PI adalah tikus model sindrom metabolik yang diberikan pakan standar sinbiotik kefir tepung pisang batu dengan dosis 1,8 mL/200 g BB tikus/hari. Kelompok PII adalah tikus model sindrom metabolik yang diberikan pakan standar sinbiotik kefir tepung pisang batu dengan dosis 3,6 mL/200 g BB tikus/hari.

Intervensi dilakukan selama 3 minggu. Populasi penelitian ini adalah tikus jenis Sprague Dawley. Penentuan jumlah sampel menggunakan ketentuan WHO yakni setiap kelompok minimal 5 ekor dengan penambahan drop out $20 \%$ sehingga didapatkan jumlah sampel sebanyak 24 ekor tikus.

Kriteria inklusi yang digunakan adalah tikus jantan, berat tubuh 150-200 g, usia tikus 8-12 minggu, dan dalam kondisi sehat. Kriteria eksklusi meliputi tikus diare dan atau mengalami penurunan berat badan lebih dari $10 \%$ dan tikus mati selama penelitian. Teknik pengambilan sampel pada penelitian ini adalah probability sampling dengan metode simple random sampling. 
Tabel 1. Pengkondisian sindrom metabolik

\begin{tabular}{ccccc}
\hline & & \multicolumn{3}{c}{ Kriteria \pm SD } \\
\cline { 3 - 4 } Kelompok & $\mathrm{N}$ & $\begin{array}{c}\text { GDP } \\
\left(\mathrm{mg} \mathrm{dL}^{-1}\right)\end{array}$ & $\begin{array}{c}\text { Trigliserida } \\
\left(\mathrm{mg} \mathrm{dL}^{-1}\right)\end{array}$ & $\begin{array}{c}\text { Kolesterol-HDL } \\
\left(\mathrm{mg} \mathrm{dL}^{-1}\right)\end{array}$ \\
\hline K- & 6 & $71,02 \pm 1,80^{\mathrm{b}}$ & $67,60 \pm 3,92^{\mathrm{b}}$ & $78,66 \pm 2,22^{\mathrm{b}}$ \\
K+ & 6 & $132,29 \pm 1,43^{* a}$ & $154,08 \pm 2,66^{* a}$ & $25,84 \pm 1,79^{*} \mathrm{a}$ \\
PI & 6 & $130,44 \pm 1,99^{* a}$ & $154,35 \pm 3,02^{* a}$ & $24,45 \pm 1,13^{* a}$ \\
PII & 6 & $131,45 \pm 2,37^{* a}$ & $155,82 \pm 2,92^{* a}$ & $25,03 \pm 2,12^{* a}$ \\
$p^{1}$ & & 0,000 & 0,000 & 0,000 \\
\hline
\end{tabular}

*Kriteria sindrom metabolik (hiperglikemia, hipertrigliseridemia, dan kadar kolesterol-HDL rendah);

a,b Notasi yang berbeda menunjukkan adanya perbedaan rerata yang signifikan pada uji lanjut Post Hoc Bonferoni;

${ }^{1}$ Uji Signifikansi One Way Anova

Subjek diaklimatisasi selama 7 hari. Pakan standar yang diberikan pada semua kelompok adalah comfeed AD II dan akuades ad libithum. Tahap selanjutnya adalah pemberian pakan high fat fructose diet (HFFD) berupa fruktosa murni $1 \mathrm{~mL} / 200 \mathrm{~g} \mathrm{BB}$ tikus/hari, kuning telur bebek $1 \mathrm{~mL} / 200 \mathrm{~g} \mathrm{BB}$ tikus/hari, dan minyak babi $2 \mathrm{~mL} / 200 \mathrm{~g} \mathrm{BB}$ tikus/hari pada kelompok kontrol positif $(\mathrm{K}+)$, kelompok perlakuan I (PI), dan kelompok perlakuan II (PII) selama 2 minggu melalui sonde lambung.

Pada kelompok kontrol positif $(\mathrm{K}+)$ dan kelompok kontrol negatif $(\mathrm{K}-)$ diberikan

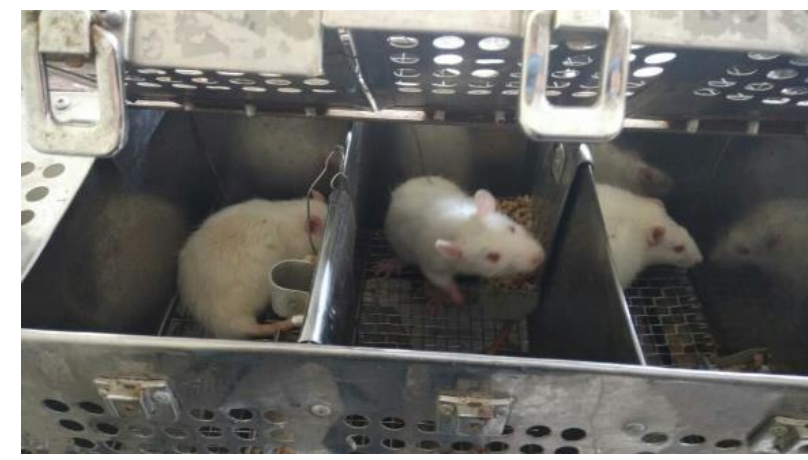

Kelompok K-

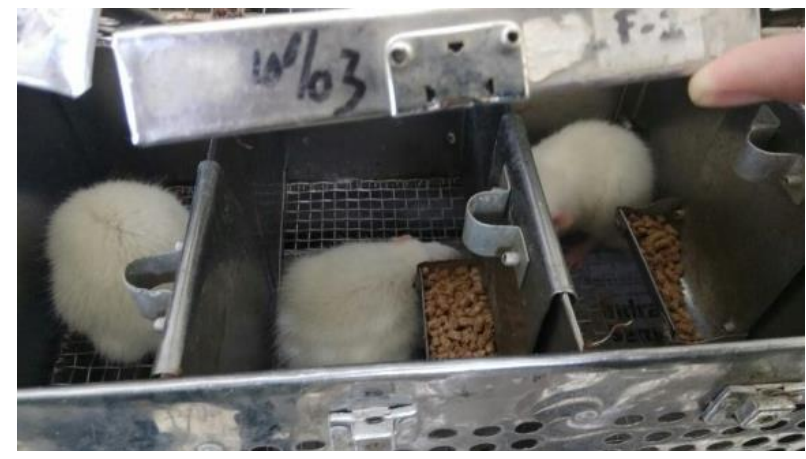

Kelompok PI pakan standar dan akuades ad libithum. Pada kelompok perlakuan I (PI) diberi pakan standar, akuades ad libithum, dan sinbiotik kefir tepung pisang batu dengan dosis 1,8 $\mathrm{mL} / 200 \mathrm{~g}$ BB tikus/hari, dan pada kelompok perlakuan II (PII) diberi pakan standar, akuades ad libithum, dan sinbiotik kefir tepung pisang batu dengan dosis 3,6 mL/200 $g$ BB tikus/hari. Pemberian sinbiotik kefir tepung pisang batu diberikan melalui sonde lambung dan dilakukan satu kali sehari yaitu pada pagi hari selama 3 minggu.

Pengambilan darah subjek dilakukan pada awal dan akhir intervensi melalui plexus

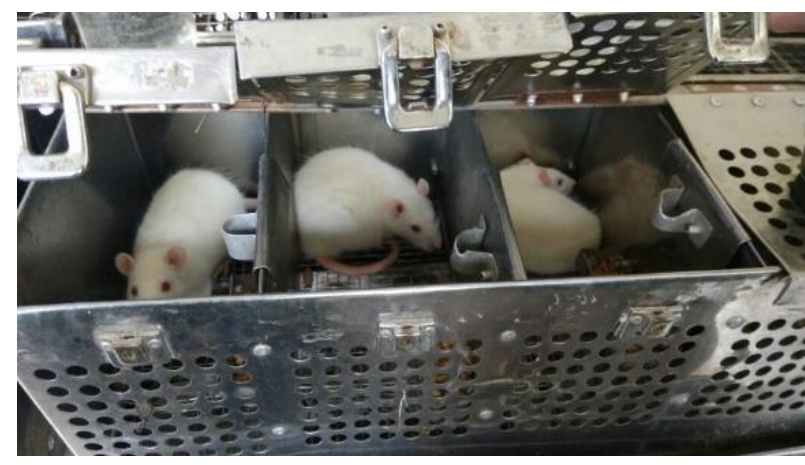

Kelompok K+

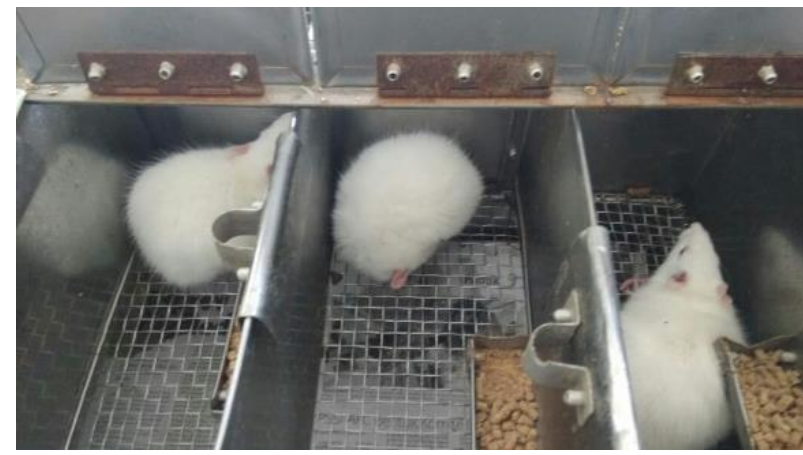

Kelompok PII

Gambar 1: hewan coba yang dibagi secara acak menjadi 4 kelompok, yaitu kelompok kontrol negatif (K-), kelompok kontrol positif $(\mathrm{K}+)$, kelompok perlakuan I (PI), dan kelompok perlakuan II (PII) 
retroorbitalis untuk menganalisis kadar kolesterol-LDL dan kolesterol-HDL. Kadar kolesterol-LDL dan kolesterol-HDL ditentukan dengan metode cholesterol oxidaseperoxidase aminoantipyrine phenol (CHODPAP) pada panjang gelombang $546 \mathrm{~nm}$ yang mengacu pada Diasys (2014a dan 2014b). Data kadar kolesterol-LDL dan kolesterolHDL diolah menggunakan software analisis statistik. Uji normalitas data dilakukan menggunakan uji Shapiro-Wilk. Perbedaan kadar kolesterol-LDL dan kolesterol-HDL sebelum dan sesudah perlakuan dianalisis menggunakan uji statistik parametrik paired sample t test.

\section{Etik penelitian}

Penelitian ini telah memperoleh persetujuan etik dari Komisi Etik Penelitian Kesehatan (KEPK) Fakultas Kedokteran, Universitas Pembangunan Nasional "Veteran" Jakarta dengan dikeluarkannya Ethical Approval nomor: B/2078/VII/2019/KEPK.

\section{HASIL DAN PEMBAHASAN}

\section{Pengkondisian sindrom metabolik}

Hasil uji normalitas data kadar glukosa darah puasa (GDP), trigliserida, dan kolesterol-HDL dilakukan dengan uji Saphiro Wilk menunjukkan data terdistribusi normal $(p>0,05)$. Untuk melihat perbedaan antarkelompok dilakukan uji lanjutan dengan uji Post Hoc Bonferoni yang dapat dilihat pada Tabel 1.

Tabel 1 menunjukkan adanya perbedaan rerata kadar GDP, trigliserida, dan kolesterol-HDL antar kelompok $(p=0,000)$. Uji lanjut yang dilakukan menunjukkan adanya perbedaan pada kelompok yang diberikan pakan HFFD, pakan standar dan akuades ad libithum di antaranya kelompok $\mathrm{K}+$, kelompok $\mathrm{PI}$, dan kelompok PII dibanding dengan kelompok K-. Rerata kadar GDP subjek kelompok $\mathrm{K}+$, kelompok PI, dan kelompok PII melebihi rerata kadar GDP kelompok K-, menunjukkan bahwa subjek yang dikondisikan sindrom metabolik mengalami hiperglikemia. Begitu juga dengan rerata kadar trigliserida subjek kelompok $\mathrm{K}+$, kelompok PI, dan kelompok PII melebihi rerata dan standar deviasi kadar trigliserida kelompok K-. Hal ini menunjukkan bahwa subjek yang dikondisikan sindrom metabolik mengalami hipertrigliseridemia.
Penurunan rerata kadar kolesterolHDL terjadi pada kelompok $\mathrm{K}+$, kelompok PI, dan kelompok PII dibanding dengan kelompok $\mathrm{K}$-, oleh karena itu subjek kelompok $\mathrm{K}+$, kelompok $\mathrm{PI}$, dan kelompok PII telah mengalami kondisi sindrom metabolik yang ditandai dengan kondisi hiperglikemia, hipertrigliseridemia, dan kadar kolesterol-HDL yang rendah. Pemberian pakan HFFD selama 3 minggu mengakibatkan terjadinya gangguan metabolisme lemak (Gropper dan Smith 2013). Asupan lemak yang tinggi membentuk timbunan lemak berlebih di jaringan adiposa. Asupan lemak jenuh dan kolesterol yang tinggi akan dicerna dalam usus halus yang akan menghasilkan trigliserida, fosfolipid, dan kolesterol yang selanjutnya akan diubah menjadi kilomikron.

Kilomikron remnant yang mengandung kolesterol tidak ter-esterifikasi disalurkan ke hati lalu dieksresikan dalam bentuk kolesterol-VLDL (very low density lipoprotein) selanjutnya terhidrolisis menjadi kolesterol-IDL (intermediate density lipoprotein) dengan bantuan lipoprotein lipase. Kolesterol-IDL akan mengalami hidrolisis kembali menjadi FFA (free fatty acid) dan gliserol sehingga berubah menjadi kolesterol-LDL yang mengandung ikatan tak jenuh yang rentan terhadap radikal bebas serta dapat membentuk plak pada dinding pembuluh darah (Gropper dan Smith 2013).

Asupan tinggi fruktosa juga dapat meningkatkan aktivitas lipogenesis menghasilkan gliserol dan asil-KoA yang akan berdampak pada peningkatan kadar trigliserida dan sekresi kolesterol-VLDL sehingga meningkatkan kadar kolesterolLDL serta meningkatkan timbunan lemak dalam hepar yang dapat menurunkan sensitivitas insulin (Ismiranda dan Dewi 2017). Sensitivitas insulin meningkatkan glukoneogenesis, yang mengakibatkan terjadinya peningkatan glukosa darah sehingga terjadi hiperglikemia (Gropper dan Smith 2013).

\section{Kadar kolesterol-LDL dan kolesterol-HDL}

Terjadi peningkatan kadar kolesterolLDL yang signifikan pada kelompok $\mathrm{K}$ - dan kelompok K+ (Tabel 2). Pada kelompok PI dan kelompok PII terjadi penurunan kadar 
Tabel 2. Kadar kolesterol-LDL ( $\mathrm{mg} \mathrm{dL}^{-1}$ ) subjek sebelum dan setelah intervensi

\begin{tabular}{|c|c|c|c|c|c|c|}
\hline \multirow{2}{*}{ Kelompok } & \multirow{2}{*}{$\mathrm{n}$} & \multirow{2}{*}{$\begin{array}{c}\text { Sebelum } \\
\text { Rerata } \pm \text { SD }\end{array}$} & \multirow{2}{*}{$\begin{array}{c}\text { Sesudah } \\
\text { Rerata } \pm \text { SD }\end{array}$} & \multirow{2}{*}{$p^{2}$} & \multicolumn{2}{|c|}{$\Delta$ Perubahan } \\
\hline & & & & & Rerata \pm SD & $\%$ \\
\hline Kontrol negatif & 6 & $23,70 \pm 2,20$ & $26,41 \pm 2,30$ & $0,001^{*}$ & $2,71 \pm 1,05$ & $11,43 \%$ \\
\hline Kontrol positif & 6 & $75,21 \pm 2,01$ & $77,62 \pm 1,98$ & $0,005^{\star}$ & $2,41 \pm 1,26$ & $3,20 \%$ \\
\hline Perlakuan I & 6 & $74,61 \pm 2,53$ & $41,30 \pm 3,26$ & $0,000^{*}$ & $-33,32 \pm 2,22$ & $-44,66 \%$ \\
\hline Perlakuan II & 6 & $78,22 \pm 1,56$ & $33,68 \pm 1,89$ & $0,000^{*}$ & $-44,54 \pm 2,12$ & $-56,94 \%$ \\
\hline
\end{tabular}

*Signifikansi Uji Paired Sample T Test

Tabel 3. Kadar kolesterol-HDL ( $\mathrm{mg} \mathrm{dL}^{-1}$ ) subjek sebelum dan setelah intervensi

\begin{tabular}{|c|c|c|c|c|c|c|}
\hline \multirow{2}{*}{ Kelompok } & \multirow{2}{*}{$\mathrm{n}$} & \multirow{2}{*}{$\begin{array}{c}\text { Sebelum } \\
\text { Rerata } \pm \text { SD }\end{array}$} & \multirow{2}{*}{$\begin{array}{c}\text { Sesudah } \\
\text { Rerata } \pm \text { SD }\end{array}$} & \multirow{2}{*}{$p^{2}$} & \multicolumn{2}{|c|}{$\Delta$ Perubahan } \\
\hline & & & & & Rerata \pm SD & $\%$ \\
\hline Kontrol negatif & 6 & $78,66 \pm 2,22$ & $76,23 \pm 2,36$ & $0,000^{*}$ & $-2,44 \pm 0,65$ & $-3,10 \%$ \\
\hline Kontrol positif & 6 & $25,84 \pm 1,80$ & $23,78 \pm 2,27$ & $0,000^{*}$ & $-2,06 \pm 0,96$ & $-7,97 \%$ \\
\hline Perlakuan I & 6 & $24,45 \pm 1,13$ & $50,00 \pm 2,55$ & $0,003^{*}$ & $25,55 \pm 1,81$ & $104,50 \%$ \\
\hline Perlakuan II & 6 & $25,03 \pm 2,20$ & $68,26 \pm 2,73$ & $0,000^{*}$ & $43,23 \pm 3,86$ & $172,71 \%$ \\
\hline
\end{tabular}

*Signifikansi Uji Paired Sample T Test

kolesterol-LDL secara signifikan. Penurunan kadar kolesterol-LDL terbesar terjadi pada kelompok PII dengan persen perubahan sebesar 56,94\%. Demikian juga dengan rerata perubahan kadar kolesterol-HDL (Tabel 3) terjadi penurunan yang signifikan pada kelompok $\mathrm{K}$ - dan $\mathrm{K}+$ setelah intervensi. Pada kelompok perlakuan terjadi peningkatan kadar kolesterol-HDL secara signifikan $(p<0,05)$. Peningkatan kadar kolesterol-HDL terbesar terjadi pada kelompok PII dengan persen perubahan sebesar $172,71 \%$.

Pangan fungsional seperti sinbiotik dapat digunakan sebagai tatalaksana non farmakologis yang bermanfaat memperbaiki kondisi sindrom metabolik (Salsabila et al. 2020). Penelitian yang dilakukan oleh Towil dan Pramono (2014) menjelaskan bahwa pemberian yoghurt sinbiotik dengan kadar BAL $10^{7}$ cfu $\mathrm{mL}^{-1}$ dapat menurunkan kadar kolesterol-LDL sebesar 20,72\%. Setelah intervensi, peningkatan kadar kolesterolLDL terjadi pada kelompok kontrol (kelompok $\mathrm{K}-$ dan kelompok $\mathrm{K}+$ ). Peningkatan yang terjadi pada kelompok $\mathrm{K}$ dapat disebabkan oleh metabolisme terhadap lemak yang semakin menurun akibat penurunan reseptor-LDL, seiring dengan pertambahan usia subjek (Mc Auley dan Mooney 2015). Sedangkan peningkatan yang terjadi pada kelompok $\mathrm{K}+$ dapat disebabkan oleh tidak adanya intervensi untuk memperbaiki kondisi tersebut. Pada kelompok kontrol juga terjadi penurunan kadar kolesterol-HDL. Penurunan kadar kolesterol-HDL yang terjadi pada kelompok $\mathrm{K}$ - disebabkan oleh mekanisme reverse cholesterol transport (RCT) yang semakin menurun seiring dengan pertambahan usia subjek (Mc Auley dan Mooney 2015). Sedangkan pada kelompok $\mathrm{K}+$, dapat disebabkan oleh kondisi sindrom metabolik sehingga kadar kolesterol-HDL tidak mampu melakukan mekanisme RCT (Gropper dan Smith 2013). Perbaikan fraksi lipid pada kelompok perlakuan berupa penurunan kadar kolesterol-LDL disebabkan oleh zat yang terkandung dalam sinbiotik, salah satunya adalah probiotik BAL. Penurunan kadar kolesterol-LDL oleh BAL dilakukan melalui mekanisme asimilasi kolesterol, dekonjugasi bile salt, degradasi kolesterol, dan adanya produksi SCFA. Proses asimilasi kolesterol melalui pengikatan kolesterol oleh BAL sehingga terjadi penurunan jumlah kolesterol (Kavitha et al. 2016).

Penurunan kadar kolesterol-LDL dapat terjadi melalui mekanisme secara tidak langsung yakni dekonjugasi bile salt dimana probiotik yang terkandung dalam sinbiotik memproduksi enzim bile salt hydrolase $(\mathrm{BSH})$, sehingga akan banyak kolesterol 
yang terpakai untuk membentuk bile salt yang kemudian akan diekskresikan melalui feses (Markowiak dan Slizewska 2017). Mekanisme lainnya yakni dengan degradasi kolesterol menjadi koprostanol sehingga kolesterol akan langsung dibuang melalui feses (Fadhilah dkk. 2015). Selain itu, kadar kolesterol-LDL turun melalui peningkatan kadar SCFA oleh sinbiotik yang memiliki efek hipotrigliserida sehingga dapat menurunkan sintesis dan produksi kolesterol-LDL (Towil dan Pramono 2014).

Selain itu, terdapat substrat atau makanan bagi probiotik yaitu prebiotik yang memiliki efek hipokolesterolemik. Beberapa jenis prebiotik seperti FOS, inulin, dan pati resisten terkandung dalam tepung pisang batu (Prayogi dkk. 2016). Efek hipokolesterolemik yang dimiliki dapat menghambat aktivitas enzim lipogenik hati melalui peningkatan SCFA sehingga pemecahan lemak dalam hati terhambat dan sekresi kolesterol-LDL menurun (Rusdiana dan Syauqy 2015), penurunan sekresi tersebut dapat meningkatkan mekanisme RCT dalam hati sehingga kadar kolesterolHDL akan meningkat.

Berdasarkan penelitiannya Abhari et al. (2015) menyebutkan bahwa pemberian kombinasi dari $5 \%$ inulin dan $10^{9} \mathrm{cfu} \mathrm{\textrm {mL } ^ { - 1 }}$ bakteri $B$. coagulans menghasilkan perbaikan fraksi lipid pada tikus hiperkolesterol. Kombinasi probiotik dan prebiotik yang membentuk sinbiotik mampu menurunkan kadar kolesterol-LDL pada tikus hiperkolesterol yang diintervensi selama 21 hari (Aktimur et al. 2017). Hasil penelitian tersebut sejalan dengan yang diperoleh Nurliyani et al. (2018) dalam penelitiannya bahwa pemberian sinbiotik dari kefir susu kambing dan glukomanan mampu menurunkan kadar kolesterol-LDL tikus jenis Sprague Dawley yang dikondisikan mengalami sindrom metabolik.

\section{KESIMPULAN}

Terjadi penurunan kadar kolesterolLDL dan peningkatan kadar kolesterol-HDL pada kedua kelompok perlakuan secara signifikan. Penurunan kadar kolesterol-LDL terbesar terjadi pada kelompok PII sebesar $56,94 \%$ dan peningkatan kadar kolesterolHDL terbesar terjadi pada kelompok PII sebesar $172,71 \%$.

\section{UCAPAN TERIMA KASIH}

Ucapan terima kasih kami sampaikan kepada Lembaga Penelitian dan Pengabdian kepada Masyarakat (LPPM), Universitas Pembangunan Nasional "Veteran" Jakarta sebagai pendukung dana penelitian.

\section{DAFTAR PUSTAKA}

Abhari K, Shekarforoush SS, Hosseinzadeh S, Nazifi S, Sajedianfard J (2015) The effects of prebiotic, probiotic and synbiotic diets containing Bacillus coagulans and inulin on serum lipid profile in the rat. Vet Sci Dev 5: 5919. doi: $10.4081 /$ vsd.2015.5919

Aktimur SH, Suher M, Darilmaz DO, Aktimur R, Ergul E (2017) Effect of probiotics, prebiotics and symbiotics on serum cholesterol levels. Clin Surg 2: 1652

Anandharaj M, Sivasankari B, Rani RP (2014) Effects of probiotics, prebiotics, and synbiotics on hypercholesterolemia: A review. Chinese J Biol 2014: 572754. doi: $10.1155 / 2014 / 572754$

Bhambhani GD, Bhambhani RG, Thakor NC (2015) Lipid profile of patients with diabetes mellitus: A cross sectional study. Int J Res Med Sci 3: 3292-3295. doi: $10.18203 / 2320-$ 6012.ijrms20151179

Carasi P, Racedo SM, Jacquot C, Romanin DE, Serradell MA, Urdaci MC (2015) Impact of kefir derived Lactobacillus kefiri on the mucosal immune response and gut microbiota. J Immunol Res 2015: 361604 . doi: $10.1155 / 2015 / 361604$

Cho YA, Kim J (2015) Effect of probiotics on blood lipid concentrations: A metaanalysis of randomized controlled trials. Medicine (Baltimore) 94: e1714. doi: 10.1097/MD.0000000000001714

Choi JW, Kang HW, Lim WC, Kim MK, Lee IY, Cho HY (2017) Kefir prevented excess fat accumulation in diet-induced obese mice. Biosci Biotechnol Biochem 81: 958-965.

doi: 10.1080/09168451.2016.1258984

Darilmaz DO, Sonmez S, Beyatli Y (2018) The effects of inulin as a prebiotic supplement and the synbiotic interactions of probiotics to improve 
oxalate degrading activity. Int J Food Sci Technol 54: 121-131. doi: 10.1111/ijfs. 13912

de Angelis-Pereira MC, Barcelos MDFP, Sousa MSB, Pereira JDAR (2013) Effects of the kefir and banana pulp and skin flours on hypercholesterolemic rats. Acta Cir Bras 28: 481-486. doi: 10.1590/S0102-86502013000700001

DiaSys (2014a) Supplementary Reagents: HDL Precipitant. DiaSys Diagnostic Systems GmbH, Holzheim, Germany

DiaSys (2014b) Supplementary Reagents: LDL Precipitant. DiaSys Diagnostic Systems GmbH, Holzheim, Germany

El-Bashiti TA, Zabut BM, Al-Krenawie Al (2017) Effect of kefir intake on growth performance and some biochemical profiles among domestic rabbits. World J Pharm Pharm Sci 6: 223-240. doi: 10.20959/wjpps20173-8801

Fadhilah AN, Hafsan, Nur F (2015) Penurunan kadar kolesterol oleh bakteri asam laktat asal Dangke secara in vitro. Pros Sem Nas Mikrobiol Kesehatan Lingk 1: 174-180. doi: 10.24252/psb.v1i1.2135

Gill RM, Khan SA, Jackson RT, Duane M (2017) Prevalence of the metabolic syndrome in Central and South American immigrant residents of the Washington DC area. J Nutr Metab 2017: 9531964 . doi: $10.1155 / 2017 / 9531964$

Gropper SS, Smith JL (2013) Advanced Nutrition and Human Metabolism. Sixth Edition. Wadsworth / Cengage Learning, Belmont USA

Hardiansyah A (2020) Identifikasi nilai gizi dan potensi manfaat kefir susu kambing Kaligesing. J Nutr Coll 9: 208-214. doi: 10.14710/jnc.v9i3.27308

Ismiranda, Dewi E (2017) Pengaruh pakan aterogenik terhadap peningkatan kadar kolesterol total serum darah mencit (Mus musculus). J EduBio Tropika 5: 14-16

Joseph N, Chettuvatti K, Yadav H, Bharadwaj $\mathrm{H}$, Kotian SM (2017) Assesment of risk of metabolic syndrome and cardio vascular diseases among medical students in India. J Cardiovasc Disease Res 8: 89-95. doi: 10.5530/jcdr.2017.3.21

Kamso S (2007) Body mass index, total cholesterol, and ratio total to $\mathrm{HDL}$ cholesterol were determinants of metabolic syndrome in the Indonesian elderly. Med J Indones 16: 195-200. doi: $10.13181 / \mathrm{mji} . v 16 i 3.276$

Kavitha K, Reddy AG, Reddy KK, Kumar CSVS, Boobalan G, Jayakanth $K$ (2016) Hypoglycemic, hypolipidemic and antioxidant effects of pioglitazone, insulin and symbiotic in diabetic rats. Vet World 9: 118-122. doi: 10.14202/vetworld.2016.118-122

Markowiak P, Slizweska K (2017) Effects of probiotics, prebiotics, and synbiotics on human health. Nutrients 9: 1021. doi: 10.3390/nu9091021

Martharini D, Indratiningsih I (2017) Kualitas mikrobiologis dan kimiawi kefir susu kambing dengan penambahan Lactobacillus acidophilus FNCC 0051 dan tepung kulit pisang kapok (Musa paradisiaca). Agritech 37: 22-29. doi: 10.22146/agritech.17002

Mc Auley MT, Mooney KM (2015) Computationally modeling lipid metabolism and aging: A mini-review. Comput Struct Biotechnol J 13: 38-46. doi: 10.1016/j.csbj.2014.11.006

Musita N (2012) Kajian kandungan dan karakteristiknya pati resisten dari berbagai varietas pisang. J Dinamika Penelitian Industri 23: 57-65

Musita N (2014) Pemanfaatan tepung pisang batu (Musa balbisiana Colla) pada pembuatan kue brownies. J Riset Industri 8: 171-178

Nur Cahyo TA, Kartasurya MI (2015) Pengaruh pemberian yoghurt kacang merah terhadap kadar kolesterol LDL pada wanita dislipidemia. J Nutr Coll 4: 133-140. doi: 10.14710/jnc.v4i2.10057

Nurliyani, Harmayanti E, Sunarti (2018) Goat milk kefir supplemented with porang glucomannan improves lipid profile and haematological parameter in rats fed high fat and high fructose diet. Rom $\mathrm{J}$ Diabetes Nutr Metab Dis 25: 11-21. doi: 10.2478/rjdnmd-2018-0002

Nurliyani, Widodo, Suranindyah Y, Rahmatulloh S (2017) Kefir fermented with glucomannan from porang tuber to improve the health of metabolic syndrome rats. Repository Universitas Gadjah Mada. Corpus ID: 90157946

Octavia ZF, Djamiatun K, Suci N (2017) Pengaruh pemberian yogurt sinbiotik 
tepung pisang tanduk terhadap profil lipid tikus sindrom metabolik. J Gizi Klinik Indones 13: 159-169. doi: 10.22146/ijcn.19369

Pandey KR, Naik SR, Vakil BV (2015) Probiotics, prebiotics and synbiotics - a review. J Food Sci Technol 52: 75777587. doi: 10.1007/s13197-015-1921-1

Pimenta FS, Luaces-Regueira M, Ton AM, Campagnaro BP, Campos-Toimil M, Mc Pereira T, Vasquez EC (2018) Mechanisms of action of kefir in chronic cardiovascular and metabolic diseases. Cell Physiol Biochem 48: 1901-1914. doi: 10.1159/000492511

Prayogi S, Fitmawati, Sofiyanti N (2016) Karakteristik morfologi dan uji kandungan nutrisi pisang batu (Musa balbisiana Colla) di Kabupaten Kuantan Singingi. J Biol Papua 8: 97-110. doi: 10.31957/jbp.59

Rahmawati FC, Djamiatun K, Suci N (2017) Pengaruh yogurt sinbiotik pisang terhadap kadar glukosa dan insulin tikus sindrom metabolik. J Gizi Klinik Indones 14: 10-18. doi: 10.22146/ijcn.19379

Rusdaina, Syauqy A (2015) Pengaruh pemberian pisang kapok (Musa paradisiaca Forma Typical) terhadap kadar trigliserida tikus Sprague Dawley pra sindrom metabolik. J Nutr Coll 4: 585-592. doi: 10.14710/jnc.v4i4.10166

Salsabila DM, Maryusman T, Fatmawati I (2020) Pengaruh sinbiotik kefir tepung pisang batu (Musa balbisiana) terhadap kadar glukosa darah tikus sindrom metabolik. J Bioteknol Biosains Indones 7: 18-27. doi: 10.29122/jbbi.v7i1.3730

Saputra S, Margawati A (2015) Pengaruh pemberian yoghurt sinbiotik tanpa lemak dengan penambahan tepung gembili (Dioscorea esculenta) terhadap kadar kolesterol total tikus hiperkolesterolemia. J Nutr Coll 4: 104109. doi: 10.14710/jnc.v4i2.10052

Srikanthan K, Feyh A, Visweshwar H, Shapiro JI, Sodhi K (2016) Systematic review of metabolic syndrome biomarkers: A panel for early detection, management, and risk stratification in the West Virginian population. Int $\mathrm{J}$ Med Sci 13: 25-38. doi: 10.7150/ijms.13800

Suhaema, Masthalina H (2015) Pola konsumsi dengan terjadinya sindrom metabolik di Indonesia. J Kesehatan Masy Nas 9: 340-347. doi: 10.21109/kesmas.v9i4.741

Tonucci LB, Dos Santos KMO, de Oliveira LL, Ribeiro SMR, Martino HSD (2017) Clinical application of probiotics in type 2 diabetes mellitus: A randomized, double-blind, placebo-controlled study. Clin Nutr 36: 85-92. doi: 10.1016/j.clnu.2015.11.011

Towil AS, Pramono A (2014) Pengaruh pemberian yoghurt sinbiotik tanpa lemak ditambah tepung gembili terhadap kadar kolesterol LDL tikus hiperkolesterolemia. J Gizi Indones 3: 46-51. doi: 10.14710/jgi.3.1.135-140

Verbeke KA, Boobis AR, Chiodini A, Edwards $C A$, Franck $A$, Kleerebezem M, Nauta A, Raes J, van Tol EAF, Tuohy KM (2015) Towards microbial fermentation metabolites as markers for health benefits of probiotics. Nutr Res Rev 28: 42-66. doi: $10.1017 /$ S0954422415000037

Wahyuni PT, Syauqy A (2015) Pengaruh pemberian pisang kapok (Musa paradisiaca Forma Typical) terhadap kadar glukosa darah puasa pada tikus Sprague Dawley pra sindrom metabolik. J Nutr Coll 4: 547-556. doi: 10.14710/jnc.v4i4.10161 